\title{
The Effect of Problem-Based Hybrid Learning (PBHL) Models on Spatial Thinking Ability and Geography Learning Outcomes
}

\author{
https://doi.org/10.3991/ijet.v15i19.15729 \\ Saiful Amin (凶) \\ Universitas Negeri Malang, Malang, Indonesia \\ Universitas Islam Negeri Maulana Malik Ibrahim, Malang, Indonesia \\ amin.geo87@pips.uin-malang.ac.id \\ Sumarmi, Syamsul Bachri, Singgih Susilo \\ Universitas Negeri Malang, Malang, Indonesia \\ Abdul Bashith \\ Universitas Islam Negeri Maulana Malik Ibrahim, Malang, Indonesia
}

\begin{abstract}
PBHL is a learning model that combines PBL with hybrid learning. This study aims to 1) determine the effect of the PBHL model on spatial thinking ability and 2) determine the effect of the PBHL model on geography learning outcomes. This study uses a quasi-experimental design of the pretestposttest control group. The research subjects were students of the Social Sciences Education Program, Universitas Islam Negeri Maulana Malik Ibrahim Malang, Indonesia. The selection of research subjects uses purposive sampling and obtained the experimental class (32 students) and the control class (28 students). This study uses the instrument of spatial thinking ability adopted from Huynh and Sharpe in the form of multiple-choice tests and the instrument of learning outcomes assessment in the form of essay tests. Data were analyzed with an independent sample t-test which was previously tested for normality and homogeneity prerequisites. The results of the study concluded that 1) the PBHL model had a significant effect on spatial thinking ability and 2) the PBHL model had a significant effect on geography learning outcomes. The average gain score of spatial thinking ability and geography learning outcomes in the experimental class is higher than the control class. Suggestions for further research with different subjects and variables, integrated e-learning application should be used to make the planning and implementation of PBHL learning easier and more successful.
\end{abstract}

Keywords-PBHL models, spatial thinking ability, geography learning outcomes. 


\section{Introduction}

Spatial thinking ability is an important skill possessed by students in studying geography. Through spatial thinking, students have academic excellence and are sensitive to the potential of the surrounding environment [1]. A person with the ability to think spatially can analyze and connect between spatial information [2], [3]. However, the facts show that students' spatial thinking ability is still low [4], [5]. This condition is assumed to affect the low geography learning outcomes.

Efforts are needed to improve students' spatial thinking ability. One of them is through PBL learning [6]. Problem-based learning model is able to encourage students to think objectively [7], critically [8], and analytically [9]. Cognitive abilities are able to shape student reasoning in investigations to solve problems contextually [10], so that student learning outcomes become high [11]. Contextual investigation requires spatial thinking ability to recognize space, apply spatial technology, and use thoughts in determining space [12].

The reason for applying the PBL model in this study is also based on the accuracy of the model in the 21 st century learning. The 21 st century learning paradigm emphasizes the ability of students to find out from various sources, formulate problems, think analytically, cooperate and collaborate in solving problems, and utilize technology and information media in their learning [13], [14].

Rational efforts that can be made to accommodate the demands of the 21 st century skills in education, namely by combining learning models with information technology in the form of e-learning. Technology in e-learning can be used as a medium to improve the quality of interactive learning between lecturers and students [15]. However, in its implementation, e-learning has weaknesses if fully implemented. It reduces the interaction between students and lecturers and between students themselves [16]. This can slow the formation of values in learning, because the role and presence of educators is paramount in the implementation of the education curriculum [11].

Weaknesses in e-learning can be overcome through blended learning or hybrid learning, which is a combination of face-to-face learning with online learning [17], [18]. This study uses the term hybrid learning because online meetings are between 60-75\% [19], [20]. Integrating the PBL model in online learning (PBHL) can mutually reinforce the positive impact of the model implemented in improving learning outcomes. The application of PBHL in this study uses the following steps. 


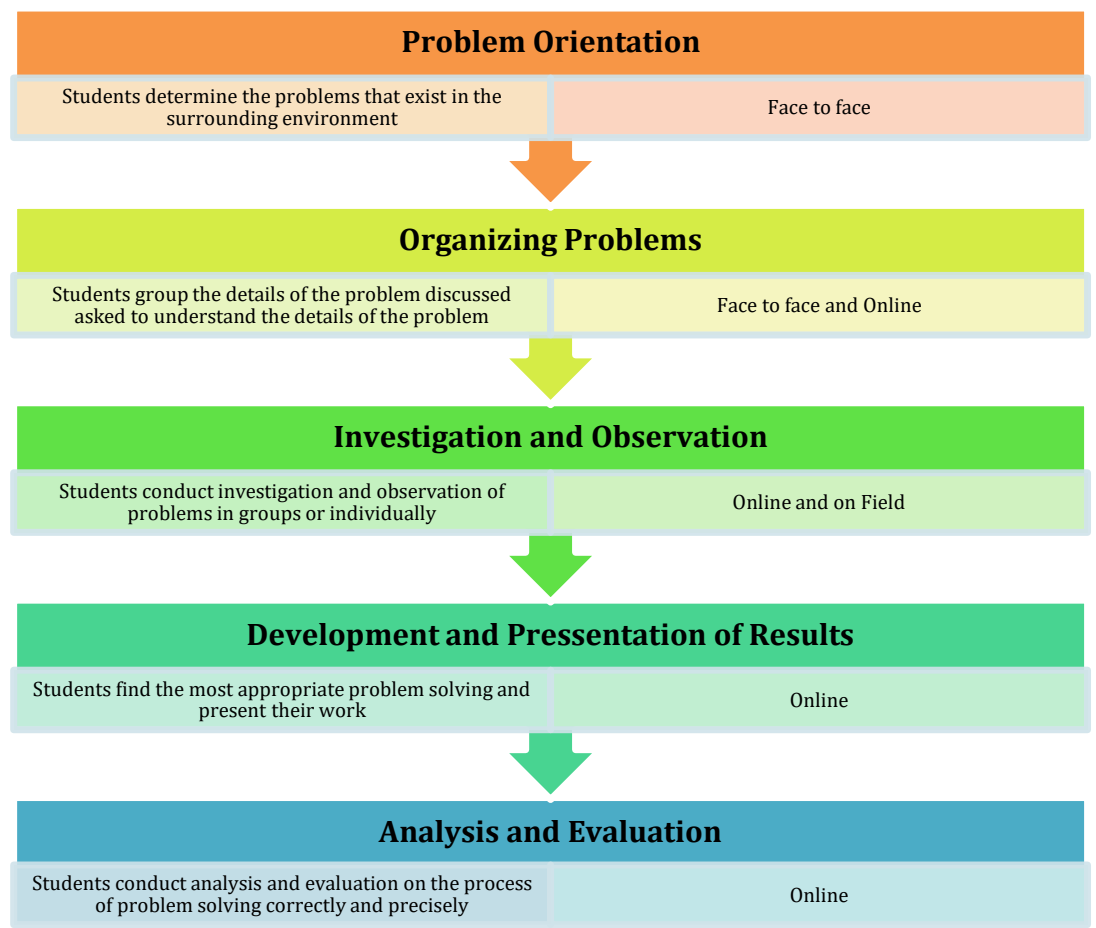

Fig. 1. PBHL Model Syntax

Research on the application of PBHL to improve spatial thinking ability and learning outcomes in geography has not been done much. Previous research that has been done only applies PBL with blended learning to improve learning outcomes [21][23], critical thinking skills [24], higher-order thinking skills [25] without spatial thinking ability variables. While research conducted by Susetyo, Sumarmi, and Astina [1] implemented PBL based on outdoor adventure education to improve spatial thinking ability without being integrated with e-learning or blended learning. This study aims to 1) determine the effect of the PBHL model on spatial thinking ability and 2) determine the effect of the PBHL model on geography learning outcomes.

\section{Methodology}

\section{$2.1 \quad$ Research design}

This study uses a quasi-experimental with the pretest-posttest control group design. Specifically, it can be seen in table 1 . 
Table 1. The Pretest-Posttest Control Group Design

\begin{tabular}{|l|c|c|c|}
\hline \multicolumn{1}{|c|}{ Class } & Pretest & Treatment & Posttest \\
\hline Experimental & $\mathrm{O}_{1}$ & $\mathrm{X}$ & $\mathrm{O}_{2}$ \\
\hline Control & $\mathrm{O}_{3}$ & - & $\mathrm{O}_{4}$ \\
\hline
\end{tabular}

Catatan:

O1 : Pretest for Experimental Class

$\mathrm{O} 2$ : Posttest for Experimental Class

$\mathrm{X}$ : PBHL Learning

O3 : Pretest for Control Class

O4 : Posttest for Control Class

- $\quad$ : Conventional Learning Integrated Blended Learning

\subsection{Participants}

The research subjects were students of the Social Sciences Education Program, Universitas Islam Negeri Maulana Malik Ibrahim Malang, Indonesia, academic year of 2019/2020. The research subjects were students who took Social Geography courses with the subject of location influence on human life. Selection of research subjects is using purposive sampling taken based on the characteristics of the same academic ability. Based on the calculation of the average learning outcomes of class B students is 66.85 and class $\mathrm{E}$ is 67.04 , then the decision was taken that class B as an experimental class amounted to 32 people and class E as a control class amounted to 28 people.

\subsection{Instrument and data collection}

The instrument used in this study is to measure spatial thinking ability adapted from Huynh and Sharpe [26]. Spatial thinking ability instrument in the form of multiple-choice tests consists of 7 questions that contain indicators: analysis, understanding, representation, application, scale, spatial interaction. Second, instruments to assess learning outcomes in geography. This instrument was made to measure student competencies after attending PBHL learning. Learning outcomes assessment instruments take the form of essay tests consisting of 5 questions.

The instruments of spatial thinking ability and geography learning outcomes were tested for validity with the product moment correlation technique. The validity test results show that both instruments are valid in the spatial thinking ability test items (table 2) and learning outcomes (table 3). Next, the reliability test of the two instruments uses Cronbach's Alpha method. The reliability test results showed that the two instruments were reliable on the spatial thinking ability test items (Alpha $=0.632)$ and geography learning outcomes $($ Alpha $=0.628)$. 
Table 2. The Validity Results of Spatial Thinking Ability

\begin{tabular}{|c|c|c|l|}
\hline Item Number & r Count & r Table & \multicolumn{1}{|c|}{ Classification } \\
\hline 1 & 0.326 & 0.284 & Valid \\
\hline 2 & 0.345 & 0.284 & Valid \\
\hline 3 & 0.321 & 0.284 & Valid \\
\hline 4 & 0.487 & 0.284 & Valid \\
\hline 5 & 0.367 & 0.284 & Valid \\
\hline 6 & 0.594 & 0.284 & Valid \\
\hline 7 & 0.538 & 0.284 & Valid \\
\hline
\end{tabular}

Table 3. The Validity Results of Geography Learning Outcomes

\begin{tabular}{|c|c|c|l|}
\hline Item Number & r Count & r Table & \multicolumn{1}{|c|}{ Classification } \\
\hline 1 & 0.513 & 0.284 & Valid \\
\hline 2 & 0.632 & 0.284 & Valid \\
\hline 3 & 0.498 & 0.284 & Valid \\
\hline 4 & 0.375 & 0.284 & Valid \\
\hline 5 & 0.454 & 0.284 & Valid \\
\hline
\end{tabular}

\subsection{Data analysis}

Data analysis in this study used statistical test of the independent sample t-test. In addition, a prerequisite test was carried out in the form of a normality test and a homogeneity test. Normality test uses Shapiro-Wilk with significance value $(\mathrm{p}>0.05)$ and homogeneity test uses Leven test with significance value $(\mathrm{p}>0.05)$. The tests are carried out by using SPSS version 21 for windows.

Hypothesis testing in this study is as follows.

H0: There is no difference in spatial thinking ability and geography learning outcomes before and after the PBHL application.

H1: there are differences in spatial thinking ability before and after the implementation of PBHL.

$\mathrm{H} 2$ : There are differences in geography learning outcomes before and after the PBHL application.

Decision making criteria:

If the significant value is $\geq 0.05$, then $\mathrm{H} 0$ is accepted. If the significant value < 0.05 , then $\mathrm{H} 0$ is rejected.

\section{Results and Discussion}

\subsection{Effect of PBHL on spatial thinking ability}

Before testing the analysis of the effect of PBHL learning on spatial thinking ability, normality and homogeneity tests were carried out. The results of the normality test of the gain data of the spatial thinking ability score are shown in table 4 and the homogeneity results of table 5 . 
Table 4. The Normality Test Results of Spatial Thinking Ability

\begin{tabular}{|l|c|c|c|}
\hline \multirow{2}{*}{\multicolumn{1}{|c|}{ Class }} & \multicolumn{3}{c|}{ Shapiro-Wilk } \\
\cline { 2 - 4 } & Statistic & $d f$ & Sig. \\
\hline Experiment & .957 & 32 & .229 \\
\hline Control & .943 & 28 & .130 \\
\hline
\end{tabular}

Table 4 shows that the results of normality test results in the spatial thinking ability of the experimental class are worth sig. $=0.229>\alpha=0.05$, while the control class is sig. $=0.130>\alpha=0.05$. Based on this significant value, it can be concluded that the gain data on spatial thinking ability scores in the experimental and control classes are normally distributed.

Table 5. The Homogeneity Test Results of Spatial Thinking Ability

\begin{tabular}{|c|c|c|c|}
\hline Levene Statistic & df1 & df2 & Sig. \\
\hline .872 & 1 & 58 & .354 \\
\hline
\end{tabular}

Table 5 shows that the value of sig. $=0.354>\alpha=0.05$, meaning that the data gain scores on spatial thinking ability in the experimental and control classes vary homogeneously.

Based on the test results of both prerequisites show that the data are normally distributed and homogeneous in variety. Then, the independent t-test sample analysis of the gain data on the spatial thinking ability score was performed to determine the effect of the PBHL model on the spatial thinking ability. A summary of the results of independent analysis of the t-test samples can be seen in Table 6.

Table 6. The Independent Sample T-Test Results of Spatial Thinking Ability

\begin{tabular}{|l|c|c|c|c|c|c|}
\hline \multicolumn{1}{|c|}{ Class } & $\mathbf{N}$ & Mean & SD & t & df & Sig. (2-tailed) \\
\cline { 1 - 4 } Experiment & 32 & 3.34 & 1.450 & \multirow{2}{*}{2.457} & \multirow{2}{*}{58} & .017 \\
\cline { 1 - 3 } Control & 28 & 2.36 & 1.660 & & & \\
\hline
\end{tabular}

Table 6 shows that the average gain score of the experimental class's spatial thinking ability is higher, which is 3.34 , than the control class, which is 2.36 . Independent test results of sample t-tests on the gain data of spatial thinking ability scores indicate that the value of sig. $=0.017<\alpha=0.05$. This means that hypothesis $\mathrm{H} 0$ is rejected and $\mathrm{H} 1$ is accepted, so it can be concluded that there are differences in spatial thinking ability before and after the implementation of PBHL. PBHL model has a significant effect on increasing the spatial thinking ability of Social Sciences Education students.

The implementation of PBHL in the subject of human geography with material on the influence of location on human life can improve students' spatial thinking ability. The stages in PBHL learning train students to conduct investigations and observations to find solutions to problems. This activity certainly requires a high spatial thinking ability because the problems that occur are in the space (location). This finding is in accordance with the results of Susetyo et al. [1] that problem solving learning affects 
the ability to think critically. The difference lies in the indicators of critical thinking skills. The previous studies used indicators from Gersmehl \& Gersmehl [3] which include geography skills: asking geographic questions, gathering information, organizing information, describing information and answering information. While, this study uses indicators of critical thinking skills from Huynh and Sharpe [26] as a measurement tool.

Spatial thinking is a combination of the concepts of space, representation, and reasoning [27]. The reasoning process allows students to combine the concepts of space and representation for decision making and problem solving through analysis, making hypotheses, generalizing, and evaluating [28]. They use the concept of space to arrange problems, find answers, and formulate solutions to the problems of everyday life [29]. The spatial thinking ability that encourages spatial intelligence becomes important in geography learning since students become more sensitive to the potential of their environment [30]. Through the ability of spatial thinking in PBHL learning, students are given the opportunity to be able to solve environmental problems [31].

\subsection{Effect of PBHL on geography learning outcomes}

The results of the normality test of the data gain score of the geography learning outcomes are shown in table 7 and the homogeneity results in table 8 .

Table 7. The Normality Test Results of Geography Learning Outcomes

\begin{tabular}{|l|c|c|c|}
\hline \multirow{2}{*}{\multicolumn{1}{|c|}{ Class }} & \multicolumn{3}{c|}{ Shapiro-Wilk } \\
\cline { 2 - 4 } & Statistic & $d f$ & Sig. \\
\hline Experiment & .979 & 32 & .763 \\
\hline Control & .975 & 28 & .728 \\
\hline
\end{tabular}

Table 7 shows that the results of the normality test of the gain data score of the learning outcomes of the experimental class geography is sig. $=0.763>\alpha=0.05$, while the control class is sig. $=0.728>\alpha=0.05$. Based on this significant value, it can be concluded that the gain data on the learning outcomes of the experimental and control class geography is normally distributed.

Table 8. The Homogeneity Test Results of Geography Learning Outcomes

\begin{tabular}{|c|c|c|c|}
\hline Levene Statistic & df1 & df2 & Sig. \\
\hline .344 & 1 & 58 & .560 \\
\hline
\end{tabular}

Table 8 shows that the value of sig. $=0.560>\alpha=0.05$, meaning that the gain data of geography learning outcomes in the experimental and control classes varies homogeneously.

Based on the test results of both prerequisites show that the data are normally distributed and homogeneous in variety. Furthermore, an independent analysis test of ttest sample of the gain score of geography learning outcomes is performed to deter- 
mine the effect of the PBHL model on geography learning outcomes. A summary of the results of independent analysis test of the t-test samples can be seen in Table 9.

Table 9. The Independent Sample T-Test Results of Geography Learning Outcomes

\begin{tabular}{|l|c|c|c|c|c|c|}
\hline \multicolumn{1}{|c|}{ Class } & N & Mean & SD & t & df & Sig. (2-tailed) \\
\hline Experiment & 32 & 24.09 & 8.767 & \multirow{2}{*}{2.147} & 58 & .036 \\
\hline Control & 28 & 19.32 & 8.380 & & & \\
\hline
\end{tabular}

Table 9 shows that the average gain score of the experimental class learning outcomes is higher, namely 24.09 than the control class, which is 19.32 . Independent test results t-test sample data gain score learning outcomes of geography shows the value of sig. $=0.036<\alpha=0.05$. This means that hypothesis $\mathrm{H} 0$ is rejected and $\mathrm{H} 2$ is accepted, so it can be concluded that there are differences in geography learning outcomes before and after the implementation of PBHL. The PBHL model has a significant effect on improving the geography learning outcomes of Social Sciences Education students.

These findings are consistent with the results of previous studies by Aeni et al. [21], Ramadhani et al. [22] dan Salari et al. [23] that the learning model for solving problems based on hybrid/blended learning is proven to have a significant effect on improving learning outcomes. The difference lies in the research subjects and the material being taught.

PBHL learning is proven to affect the learning outcomes of geography, allegedly because during its implementation, it presents authentic problems around their environment. The process for solving problems like this, not only requires students' material knowledge but also develops the ability to think critically and analytically about the environment of daily life [32], [33]. Through PBHL learning students are encouraged to be sensitive to the problems that present in their environment. Problems raised in PBHL learning in the process of solving require investigation and direct observation in the field. Students understand the problem better in detail and concretely, making it easier to extract data and information to determine and decide on a solution.

The hybrid learning system in the PBHL model influences the increase in geography learning outcomes. The results of this study are supported by a research from Hariadi et al. [34] dan Ridwan et al. [35] which concludes that hybrid / blended learning improves learning outcomes and learning development. Students have more time in searching sources of data and information online that have not been obtained in the field. Students' knowledge becomes rich as a provision to develop solutions to the problems they face [36]. Therefore, PBHL in addition to influencing the improvement of geography learning outcomes, also allows students to master information technology better. This has become the provision of Social Science Education students to face the global demands of information technology development in the 21 st century. 


\section{Conclusion}

The results of the study concluded that 1 ) the PBHL model had a significant effect on spatial thinking ability and 2) the PBHL model had a significant effect on geography learning outcomes. The results of the study are shown by:

- Significant improvement in spatial thinking ability and student learning outcomes at the significance level $\alpha=5 \%$.

- The average gain score of spatial thinking ability and learning outcomes of geography in the experimental class is higher than the control class.

- The average gain score of the experimental class learning outcomes is higher than the control class.

Researchers use hybrid learning systems with mixed applications, namely WhatsApp, email, zoom, and Google form, so it is recommended in further research to use one integrated e-learning application. It is intended to make the preparation of PBHL learning plans easier, and the application of PBHL learning can be more successful.

\section{Acknowledgement}

Thank you to students of Social Sciences Education, Universitas Islam Negeri Maulana Malik Ibrahim Malang and all those who have helped researchers in conducting this research.

\section{References}

[1] B. B. Susetyo, Sumarmi, and I. K. Astina, "Pengaruh Pembelajaran Problem Based Learning Berbasis Outdoor Adventure Education Terhadap Kecerdasan Spasial," Jurnal Pendidikan: Teori, Penelitian, dan Pengembangan, vol. 2, no. 12, p. 1669-1675, 2017.

[2] M. Aliman, "Model Pembelajaran Group Investigation Berbasis Spasial Thinking," in Prosiding Seminar Nasional Geografi 2016, Padang, 2016, vol. 1, pp. 58-68.

[3] P. J. Gersmehl and C. A. Gersmehl, "Spatial Thinking: Where Pedagogy Meets Neuroscience," Problems of Education in the 21st Century, vol. 27, pp. 48-66, 2011, [Online]. Available: http://journals.indexcopernicus.com/abstract.php?icid=937750.

[4] J. Fleming and J. Mitchell, "Effects of Giant Traveling Map Use on Student Spatial Thinking," The Geographical Bulletin, vol. 58, pp. 67-77, 2017.

[5] B. Istifarida, S. Santoso, and Y. Yusup, "Pengembangan E-Book Berbasis Problem Based Learning-GIS untuk Meningkatkan Kecakapan Berfikir Keruangan pada Siswa Kelas X SMAN 1 Sragen 2016/2017," GeoEco, vol. 3, no. 2, pp. 133-144, Jul. 2017, Accessed: Apr. 06, 2020. [Online]. Available: https://jurnal.uns.ac.id/GeoEco/article/view/14308. https://doi.org/10.20961/paedagogia.v20i2.8596

[6] N. T. Huynh, "The Role of Geospatial Thinking and Geographic Skills in Effective Problem Solving with GIS: K-16 Education," Library and Archives Canada = Bibliothèque et Archives Canada, Ottawa, 2010.

[7] Sumarmi, Model-Model Pembelajaran Geografi. Malang: Aditya Media Publishing, 2015. 
[8] A. Bashith and S. Amin, "The Effect of Problem Based Learning on EFL Students' Critical Thinking Skill and Learning Outcome," Al-Ta lim Journal, vol. 24, no. 2, pp. 93-102, Jul. 2017, https://doi.org/10.15548/jt.v0i0.271.

[9] K. Ware and E. Rohaeti, "Penerapan Model Problem Based Learning dalam Meningkatkan Kemampuan Berpikir Analitis dan Keterampilan Proses Sains Peserta Didik SMA," j.tadris.kimiya, vol. 3, no. 1, p. 217, Jun. 2018, https://doi.org/10.15575/jtk.v3i1.2219.

[10] J. A. Orozco and R. T. Yangco, "Problem-Based Learning: Effects on Critical and Creative Thinking Skills in Biology,” Asian Journal of Biology Education, vol. 9, pp. 3-10, 2016.

[11] Sumarmi, S. Bachri, L. Yuda Irawan, D. B. Perdana Putra, Risnani, and M. Aliman, "The Effect of Experiential Learning Models on High School Students Learning Scores and Disaster Countermeasures Education Abilities," Journal for the Education of Gifted Young Scientists, vol. 8, no. 1, pp. 61-85, Mar. 2020, https://doi.org/10.17478/jegys.635632.

[12] S. Metoyer and R. Bednarz, "Spatial Thinking Assists Geographic Thinking: Evidence from a Study Exploring the Effects of Geospatial Technology," Journal of Geography, vol. 116, no. 1, pp. 20-33, 2017, https://doi.org/10.1080/00221341.2016.1175495.

[13] M. Bialik and C. Fadel, Skills for the 21st Century: What Should Students Learn? Boston: Montes Alti Educational Foundation, 2015.

[14] U. A. Chaeruman, "Pembelajaran Abad 21," presented at the Seminar Nasional Pembelajaran Abad 21 Pusdiklat Kemdikbud, Sawangan, 2018.

[15] P. Pratama, "Pengembangan Pembelajaran E-learning Berbasis Moodle pada Materi Pedosfer Kelas X Sekolah Menengah Atas.” Pascasarjana Universitas Negeri Malang, 2011.

[16] V.-M. Cojocariu, I. Lazar, and G. Lazar, "The Ambivalence of Strengths and Weaknesses of E-Learning Educational Services," BRAIN. Broad Research in Artificial Intelligence and Neuroscience, vol. 7, no. 3, p. 20, 2016.

[17] K. Shand and S. G. Farrelly, "The Art of Blending: Benefits and Challenges of a Blended Course for Pre-Service Teachers," JEO, vol. 15, no. 1, pp. 1-15, Jan. 2018, https://doi.org/ 10.9743/jeo2018.15.1.10

[18] B. F. Klimova and J. Kacetl, "Hybrid Learning and its Current Role in the Teaching of Foreign Languages," Procedia - Social and Behavioral Sciences, vol. 182, pp. 477-481, May 2015, https://doi.org/10.1016/j.sbspro.2015.04.830.

[19] D. Widyartono, "Model Pembelajaran Menulis Karya Ilmiah dengan Pendekatan Hybrid Learning.” Pascasarjana Universitas Negeri Malang, 2018, [Online]. Available: http:// karya-ilmiah.um.ac.id/index.php/disertasi/article/view/77019. https://doi.org/10.31227/osf. io/vp2bz

[20] S. Hall and D. Villareal, "The Hybrid Advantage: Graduate Student Perspectives of Hybrid Education Courses," International Journal of Teaching and Learning in Higher Education, vol. 27, no. 1, pp. 69-80, 2015, [Online]. Available: http://www.isetl.org/ijtlhe/.

[21] N. Aeni, T. Prihatin, and Y. Utanto, "Pengembangan Model Blended Learning Berbasis Masalah pada Mata Pelajaran Sistem Komputer," Innovative Journal of Curriculum and Educational Technology (IJCET), vol. 6, no. 2, pp. 84-97, 2017.

[22] R. Ramadhani, R. Umam, A. Abdurrahman, and M. Syazali, "The Effect of FlippedProblem Based Learning Model Integrated With LMS-Google Classroom for Senior High School Students," Journal for the Education of Gifted Young Scientists, vol. 7, no. 2, pp. 137-158, Jun. 2019, https://doi.org/10.17478/jegys.548350.

[23] M. Salari, A. Roozbehi, A. Zarifi, and R. A. Tarmizi, "Pure PBL, Hybrid PBL and Lecturing: which one is more effective in developing cognitive skills of undergraduate students in pediatric nursing course?," BMC Med Educ, vol. 18, no. 1, pp. 1-15, Dec. 2018, https:// doi.org/10.1186/s12909-018-1305-0 
[24] C. Alfi, S. Sumarmi, and Ach. Amirudin, "Pengaruh Pembelajaran Geografi Berbasis Masalah dengan Blended Learning terhadap Kemampuan Berpikir Kritis Siswa SMA,” Jurnal Pendidikan: Teori, Penelitian, dan Pengembangan, vol. 1, no. 4, p. 597—602, 2016. https:// doi.org/10.17977/um017v20i12015p048

[25] S. Suhirman, Y. Yusuf, A. Muliadi, and S. Prayogi, "The Effect of Problem-Based Learning with Character Emphasis toward Students' Higher-Order Thinking Skills and Characters," Int. J. Emerg. Technol. Learn., vol. 15, no. 06, p. 183, 2020, https://doi.org/10.3991/ ijet.v15i06.12061

[26] N. T. Huynh and B. Sharpe, "An Assessment Instrument to Measure Geospatial Thinking Expertise," Journal of Geography, vol. 112, no. 1, pp. 3-17, Jan. 2013, https://doi.org/10. $\underline{1080 / 00221341.2012 .682227}$

[27] National Research Council (NRC), Learning to Think Spatially: GIS as a Support System in The K-12 Curriculum. Washington, D.C: The National Academies Press, 2006.

[28] I. Jo, "Spatial Thinking in Secondary Geography: a Summary of Research Findings and Recommendations for Future Research," Boletim Paulista de Geografia, vol. 99, pp. 200$212,2018$.

[29] C. Charcharos, M. Kokla, and E. Tomai, "Investigating the Influence of Spatial Thinking in Problem Solving," AGILE, pp. 14-17, 2016.

[30] Hartono, "Pendidikan Geografi di Era Global: Tinjauan Substantif di Era program Nawa Cita dan Isu Dunia.” Kuliah Tamu Geografi, Jurusan Geografi, FIS, UM, 2015. https://doi. org/10.31227/osf.io/jx8rp

[31] J. Lee and R. Bednarz, "Components of Spatial Thinking: Evidence from a Spatial Thinking Ability Test," Journal of Geography, vol. 111, no. 1, pp. 15-26, Jan. 2012, https://doi. org/10.1080/00221341.2011.583262.

[32] D. T. Tiruneh, M. De Cock, and J. Elen, "Designing Learning Environments for Critical Thinking: Examining Effective Instructional Approaches," Int J of Sci and Math Educ, vol. 16, no. 6, pp. 1065-1089, Aug. 2018, https://doi.org/10.1007/s10763-017-9829-z.

[33] A. Nurkhin, K. Kardoyo, H. Pramusinto, R. Setiyani, and R. Widhiastuti, "Applying Blended Problem-Based Learning to Accounting Studies in Higher Education; Optimizing the Utilization of Social Media for Learning," International Journal of Emerging Technologies in Learning (iJET), vol. 15, no. 08, pp. 22-39, Apr. 2020, Accessed: May 10, 2020. [Online]. Available: https://online-journals.org/index.php/i-jet/article/view/12201. https:// doi.org/10.3991/ijet.v15i08.12201

[34] B. Hariadi, D. Sunarto, P. Sudarmaningtyas, and B. Jatmiko, "Hybrid Learning by Using Brilian Applications as One of the Learning Alternatives to Improve Learning Outcomes in College," International Journal of Emerging Technologies in Learning (iJET), vol. 14, no. 10, pp. 34-45, May 2019, Accessed: May 10, 2020. [Online]. Available: https://onlinejournals.org/index.php/i-jet/article/view/10150. https://doi.org/10.3991/ijet.v14i10.10150

[35] R. Ridwan, H. Hamid, and I. Aras, "Blended Learning in Research Statistics Course at The English Education Department of Borneo Tarakan University," International Journal of Emerging Technologies in Learning (iJET), vol. 15, no. 07, pp. 61-73, Apr. 2020, Accessed: May 10, 2020. [Online]. Available: https://online-journals.org/index.php/i-jet/ article/view/13231. https://doi.org/10.3991/ijet.v15i07.13231

[36] S. Amin, "Pengaruh Model Pembelajaran Problem Based Learning (PBL) terhadap Hasil Belajar Geologi Mahasiswa UIN Maulana Malik Ibrahim Malang,” J-PIPS, vol. 1, no. 2, pp. 285-314, 2015. https://doi.org/10.18860/jpips.v1i2.6824 


\section{Authors}

Saiful Amin is a lecturer at Departement of Social Science Education, Faculty of Tarbiyah and Teacher Training, Universitas Islam Negeri Maulana Malik Ibrahim Malang, Indonesia. Currently, he is studying a doctoral program at Department of Geography Education, Faculty of Social Science, Universitas Negeri Malang, Indonesia. Field of expertises are in geography learning, education \& teacher training, social studies education.

Sumarmi is a professor, lecturer, and researcher at Department of Geography Education, Faculty of Social Science, Universitas Negeri Malang, Indonesia. Field of expertises are in environmental geography, geography learning, and environmental education based on local wisdom.

Syamsul Bachri is an associate professor, lecturer, and researcher at Department of Geography Education, Faculty of Social Science, Universitas Negeri Malang, Indonesia. Field of expertises are in disaster especially volcano, watershed management and geomorphology.

Singgih Susilo is an associate professor, lecturer, and researcher at Department of Geography Education, Faculty of Social Science, Universitas Negeri Malang, Indonesia. Field of expertises are in population sciences, demographic science, and population geography.

Abdul Bashith is a doctor, lecturer, and researcher at Department of Social Science Education, Faculty of Tarbiyah and Teacher Training, Universitas Islam Negeri Maulana Malik Ibrahim Malang, Indonesia. Field of expertises are in education \& teacher training, social studies education, and economic \& entrepreneurship learning.

Article submitted 2020-05-25. Resubmitted 2020-06-26. Final acceptance 2020-06-28. Final version published as submitted by the authors. 